\title{
Germinal vesicle breakdown in oocytes of human atretic follicles during the menstrual cycle
}

\author{
A. Gougeon and J. Testart \\ Physiologie et Psychologie de la Reproduction humaine, INSERM U-187, 32 rue des Carnets, \\ 92140 Clamart, France
}

\begin{abstract}
Summary. Histological examination was performed on 975 antral follicles (1-12 mm) from 17 large ovarian resections and 79 whole ovaries collected from 63 women with normal ovarian function at different stages during the menstrual cycle. The meiotic stage of the oocyte was examined in relation to the degree of atresia and size of follicles throughout the menstrual cycle. In healthy follicles the oocytes were in the dictyate stage. In atretic follicles $10 \%$ of the oocytes exhibited germinal vesicle breakdown (GVBD) and $20 \%$ were necrotic. The percentage of GVBD oocytes in atretic follicles was closely related to the degree of follicular atresia and to the follicle diameter. GVBD percentage rose sharply in the periovulatory period although there was no change of mean follicle size or quality during this period. Such a cyclic evolution in GVBD percentages indicates that the removal of inhibition (due to atresia) exerted by the follicle itself on the germinal vesicle is insufficient to induce the resumption of meiosis in the human oocyte; specific induction seems to be necessary, at least to produce complete nuclear maturation.
\end{abstract}

\section{Introduction}

In mammals, meiosis is initiated in oocytes during fetal development but becomes arrested in late prophase (dictyate stage) at about the time of birth. At this moment the oocyte contains a large nucleus called the germinal vesicle (GV). It is generally accepted that the resumption of the arrested first meiotic division (germinal vesicle breakdown: GVBD) results from the LH surge during each ovarian cycle, but also occurs spontaneously in atretic ovarian follicles (Ingram, 1962). Using pig and cattle intrafollicular oocytes, Foote $\&$ Thibault (1969) have demonstrated the role of follicular cells in the inhibition of meiosis. The blockade of meiosis could be due to a non-steroid inhibitor: e.g. a follicular peptide (oocyte meiosis inhibitor, OMI) synthesized by the granulosa and cumulus cells (Tsafriri, Pomerantz \& Channing, 1976) or a purine base, hypoxanthine (Downs, Coleman, Ward-Bailey \& Eppig, 1985). Because of the disappearance of the granulosa, follicular atresia could be responsible for a removal of inhibition, as occurs when the oocyte is removed from its follicle (review by Thibault, 1977).

Nevertheless, although OMI has been detected in the follicular fluid of sows and women (Channing \& Pomerantz, 1981), spontaneous resumption of oocyte meiosis in vivo has not been observed in sow atretic follicles (Cran, Osborn \& Rushton, 1983) and scarcely in the human (Allen, Pratt, Newell \& Bland, 1930; Pincus \& Saunders, 1939; Friedrich, Breitenecker, Pavelka \& Golob, 1975; Sanyal, Taymor \& Berger, 1976; McNatty, Moore Smith, Makris, Osathanondh \& Ryan, 1979; Seibel, Smith, Levesque, Borten \& Taymor, 1982). Such a situation appears to be in contradiction with the concept of meiosis inhibition by a substance synthesized by the granulosa cells, since in atretic follicles these cells are profoundly altered.

The exact nature of the mechanisms triggering the resumption of meiosis in mammals is controversial; for example in women, GVBD may be due to the removal of an inhibitor (OMI 
or hypoxanthine) or to the induction by a meiosis inducing substance (MIS), as suggested by Westergaard, Byskov, Andersen, Grinsted \& McNatty (1984). The study of oocyte evolution in atretic follicles in vivo could be one means of gaining a better understanding of these mechanisms.

We have therefore carried out histological analysis of oocytes contained in all follicles $>1 \mathrm{~mm}$ in diameter from human ovaries; preovulatory follicles were discarded. We distinguished the respective influences of the periods in the menstrual cycle, the quality and the size of the follicle on oocyte meiotic status.

\section{Materials and Methods}

Experimental subjects and sampling. Material (79 whole ovaries and 17 large ovarian resections) was obtained from 63 women undergoing surgery for various gynaecological disorders not directly related to pathological conditions of the ovary (ovariectomy for carcinoma of the breast or cervix, uterine fibroids). The patients were aged 18 to 49 years; $<30$ years; $N=9 ; 31-35$ years: $N=11$; 36-40 years: $N=11 ; 41-45$ years: $N=19$; and $>45$ years: $N=13$. All had regular menstrual cycles (mean \pm s.d. $=28 \pm 3$ days) and had not had recent hormonal treatment. The breakdown of sampling is shown in Table 1. The date of the previous menstrual period, the examination of the endometrial histology (18 cases) and circulating gonadotrophin and steroid levels (12 cases) were used to determine the approximate stage of the cycle at which the samples were taken. The ovarian histology was taken as a more precise indicator; the follicle destined to ovulate showed morphometric characteristics closely related to each of the three follicular-phase periods (Bomsel Helmreich et al., 1979; Gougeon \& Lefèvre, 1983) and histological dating of the cyclic corpus luteum was used for the three luteal-phase periods (Corner, 1956; A. Gougeon, unpublished data). The theoretical 28-day menstrual cycle was divided into 6 stages: early (Days 1-5), middle (Days 6-10) and late (Days 11-14) follicular phase, and early (Days 15-19), middle (Days 20-24) and late (Days 25-28) luteal phase. The ovarian samples showing a preovulatory follicle (late follicular phase, LF) were classified into three phases according to Bomsel-Helmreich et al. (1979): Phase I, during the plasma oestradiol rise; Phase II, between the oestradiol peak and the LH surge; Phase III, between the LH surge and ovulation. Healthy follicles $>12 \mathrm{~mm}$ in diameter (preovulatory follicles) were not analysed in this study.

Table 1. Origin of the analysed oocytes

\begin{tabular}{|c|c|c|c|c|c|c|c|c|c|}
\hline & \multirow[t]{2}{*}{$\mathrm{EF}$} & \multirow[t]{2}{*}{ MF } & \multicolumn{3}{|c|}{ LF } & \multirow[t]{2}{*}{ EL } & \multirow[t]{2}{*}{ ML } & \multirow[t]{2}{*}{ LL } & \multirow[t]{2}{*}{ Total } \\
\hline & & & I & II & III & & & & \\
\hline No. of patients & 7 & 9 & 4 & 8 & 9 & 13 & 8 & 5 & 63 \\
\hline No. of ovaries & 11 & 10 & 6 & 7 & 5 & 17 & 14 & 9 & 79 \\
\hline No. of ovarian resections & 2 & 2 & 0 & 3 & 6 & 4 & 0 & 0 & 17 \\
\hline No. from atretic follicles & 114 & 88 & 71 & 69 & 44 & 123 & 126 & 55 & 690 \\
\hline No. from healthy follicles & 61 & 59 & 32 & 20 & 14 & 61 & 17 & 27 & 291 \\
\hline
\end{tabular}

* Phases of the menstrual cycle: $\mathrm{EF}=$ early follicular; $\mathrm{MF}=$ mid-follicular; $\mathrm{LF}=$ late follicular; $\mathrm{EL}=$ early luteal; $\mathrm{ML}=$ mid-luteal; $\mathrm{LL}=$ late luteal.

Figs $1 \&$ 2. Early atresia in a middle-sized follicle $(2.0-4.9 \mathrm{~mm})$; the shape is regular and despite numerous pycnotic cells, theca (th.) and granulosa (gr.) layers are not markedly altered Fig. 1, $\times 30$; Fig. $2, \times 480$.

Figs 3 \& 4. Marked atresia in a middle-sized follicle $(2 \cdot 0-4.9 \mathrm{~mm})$; the shape remains regular, contrary to the theca interna (th.) the remaining granulosa cells (gr.) are markedly altered. The cumulus starts to dissociate. Fig. 3, × 30; Fig. 4, $\times 480$. 

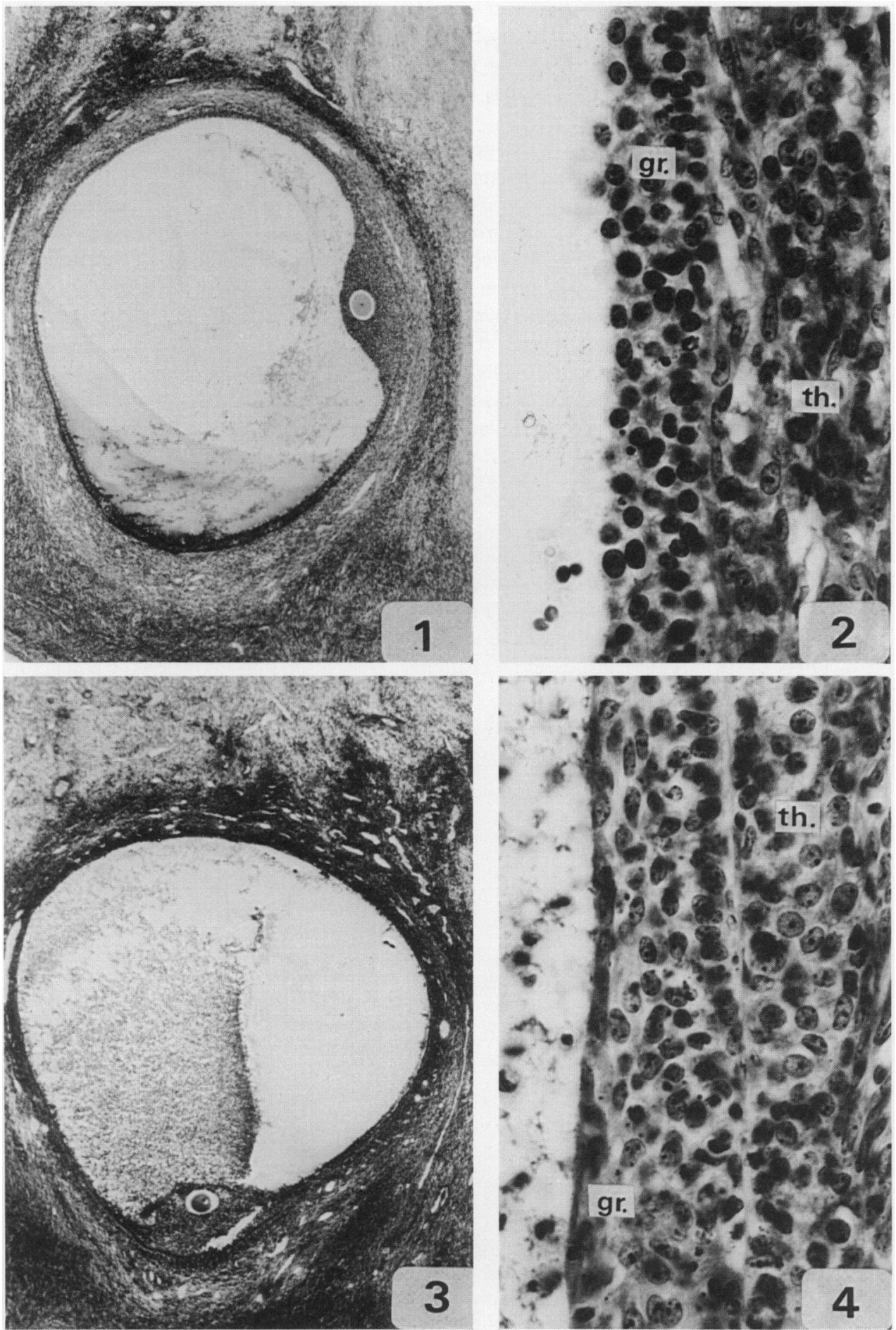
Histological methods and follicle classification. The samples were fixed in Bouin's fluid or alcohol formaldehyde acetic acid within $20 \mathrm{~min}$ after sampling; they were serially sectioned at $10 \mu \mathrm{m}$ and then stained with haematoxylin-Masson blue. The entire population of growing follicles of $1-12 \mathrm{~mm}$ in diameter was examined then divided into 3 size classes: $1 \cdot 0-1 \cdot 9,2 \cdot 0-4.9$ and $\geqslant 5 \mathrm{~mm}$. The follicles $<1 \mathrm{~mm}$ were discarded because of precocious disappearance of the oocyte when these follicles became atretic.

The follicles were classified into 5 categories according to the quality of the follicle wall: (i) healthy follicles in which the granulosa pycnotic index never exceeded $0.2 \%$ (Bomsel Helmreich et al., 1979); (ii) early atresia in which the granulosa pycnotic index was $>0.2 \%$ and the granulosa wall was well conserved (Figs $1 \& 2$ ); (iii) marked atresia for which the granulosa pycnotic index was $>2.5 \%$ and $<50 \%$ of the granulosa wall had disappeared; the shape of the follicle was ovoid or spherical; the theca interna was well preserved (Figs $3 \& 4$ ); (iv) late atresia in which the cumulus oophorus persisted despite the disappearance of the granulosa cells, the theca interna was transformed into interstitial gland, and the basal lamina was thickened and presented a thin strip of connective cells in its inner part; the follicle shape was irregular (Figs $5 \& 6$ ); and (v) very late atresia in which the granulosa, the cumulus and the interstitial gland had disappeared; often the oocyte was free in the antrum which was invaded by connective tissue (Figs $7 \& 8$ ).

Oocyte classification. According to the appearance of the nucleus the oocyte was classified in the following groups. (i) For the germinal vesicle (GV) at the dictyate or prometaphase stages (Figs 9 \& 10 ), the prometaphase nuclei no longer had the typical appearance of the dictyate nucleus, the chromatin was condensed around a clear nucleolus and the GV was situated at the periphery of the ooplasm. (ii) For germinal vesicle breakdown (GVBD), for oocyte showed a chromatin mass, a metaphase 1 spindle or a polar body (PB) (Figs 11-13). (iii) For necrotic oocytes the degenerative process had led to oocyte subnuclei (Meyer \& Longo, 1979), fragmentation and an empty zona pellucida (Figs 14-16). In these last cases macrophages were often present inside the zona pellucida.

Altogether, 975 follicles of $>1 \mathrm{~mm}$ in diameter and their 981 oocytes were examined; 684 of these follicles in which 690 oocytes were observed were atretic. For each period of 5 days in the menstrual cycle, 55-184 oocytes were observed in atretic follicles (Table 1).

Statistical methods. The statistical significance of the observed differences was determined by Student's $t$ and $\chi^{2}$ tests as appropriate.

\section{Results}

\section{Oocyte status and stage of follicle atresia}

The oocytes of healthy follicles always presented a germinal vesicle (Table 2). They were in the dictyate $(91 \%)$ or in the prometaphase $(9 \%)$ stages. The percentage of oocytes with a germinal vesicle was $70 \%(486 / 690)$ in the population of atretic follicles. These oocytes were in the dictyate $(16 \%)$ or prometaphase $(84 \%)$ stages. Amongst the GV oocytes from healthy or atretic follicles

Figs 5 \& 6. Late atresia in a middle-sized follicle $(1.0-1.9 \mathrm{~mm})$; the shape starts to be irregular. Granulosa cells have disappeared whereas theca cells have changed into an interstitial gland (i.g.); the oocyte is free of cumulus cells. Fig. 5, × 30; Fig. 6, × 480.

Figs $7 \& 8$. Very late atresia in a mid-size follicle $(1 \cdot 0-1.9 \mathrm{~mm})$; the shape is irregular. Both interstitial gland and cumulus cells have disappeared, the basal lamina (b.1.) and the fibroblast layer (f.) in the inner part of the antrum are very thick. The oocyte is floating free in the follicular fluid. Fig. 7, × 30; Fig. 8, × 480 . 

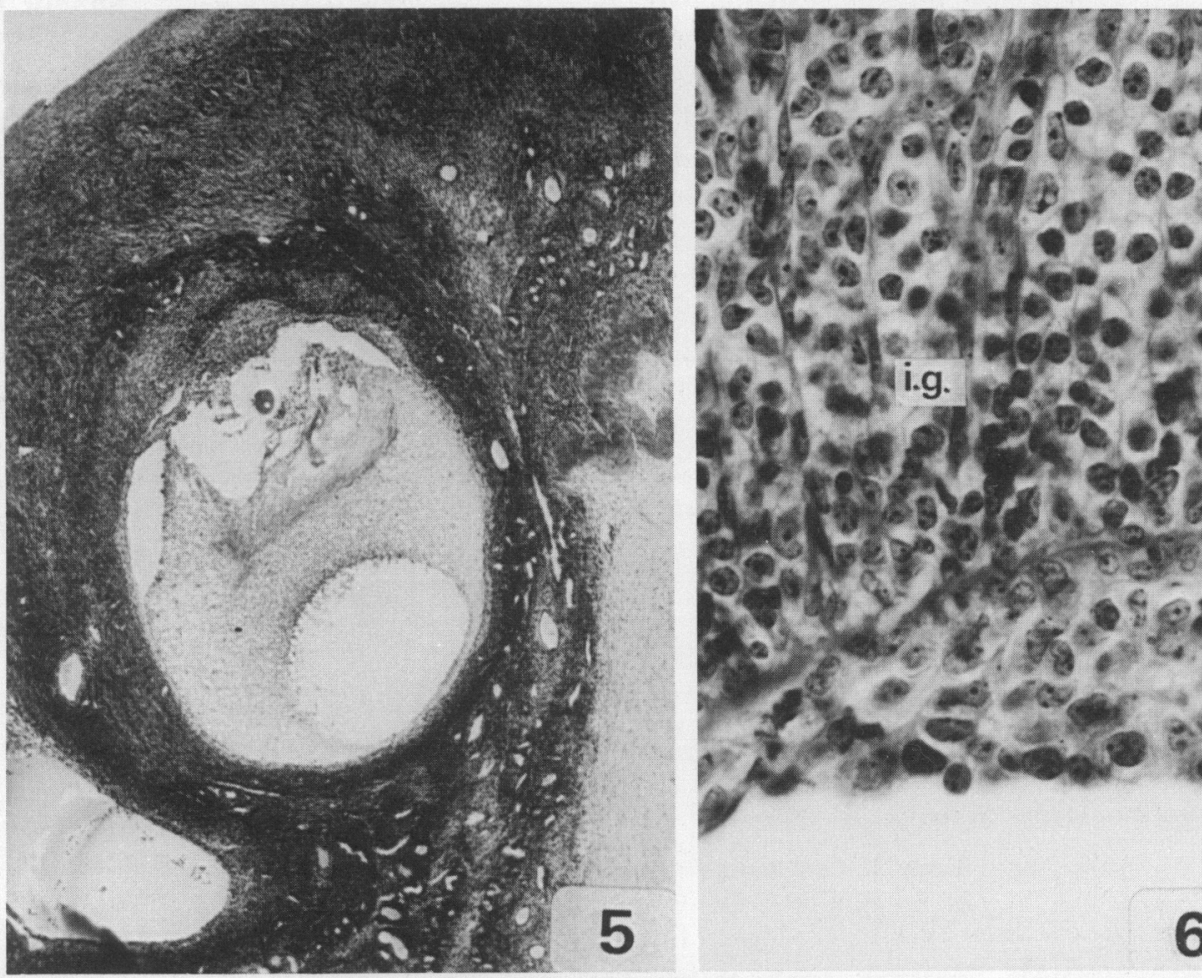

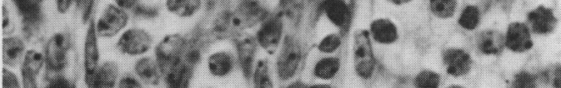

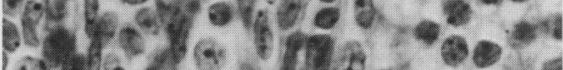

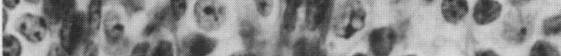

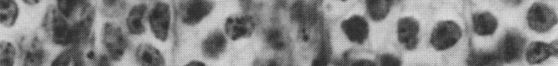

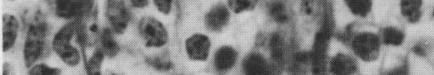

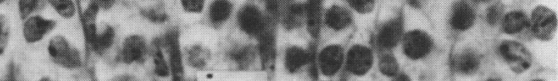
16. ${ }^{2}$ i.g.

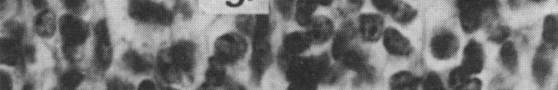

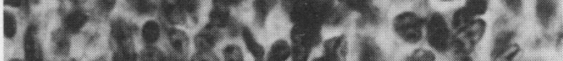

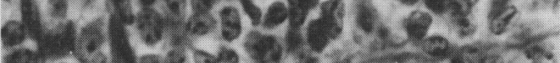

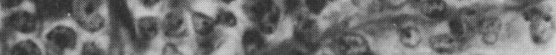

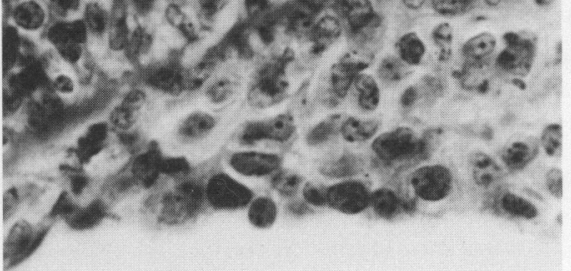
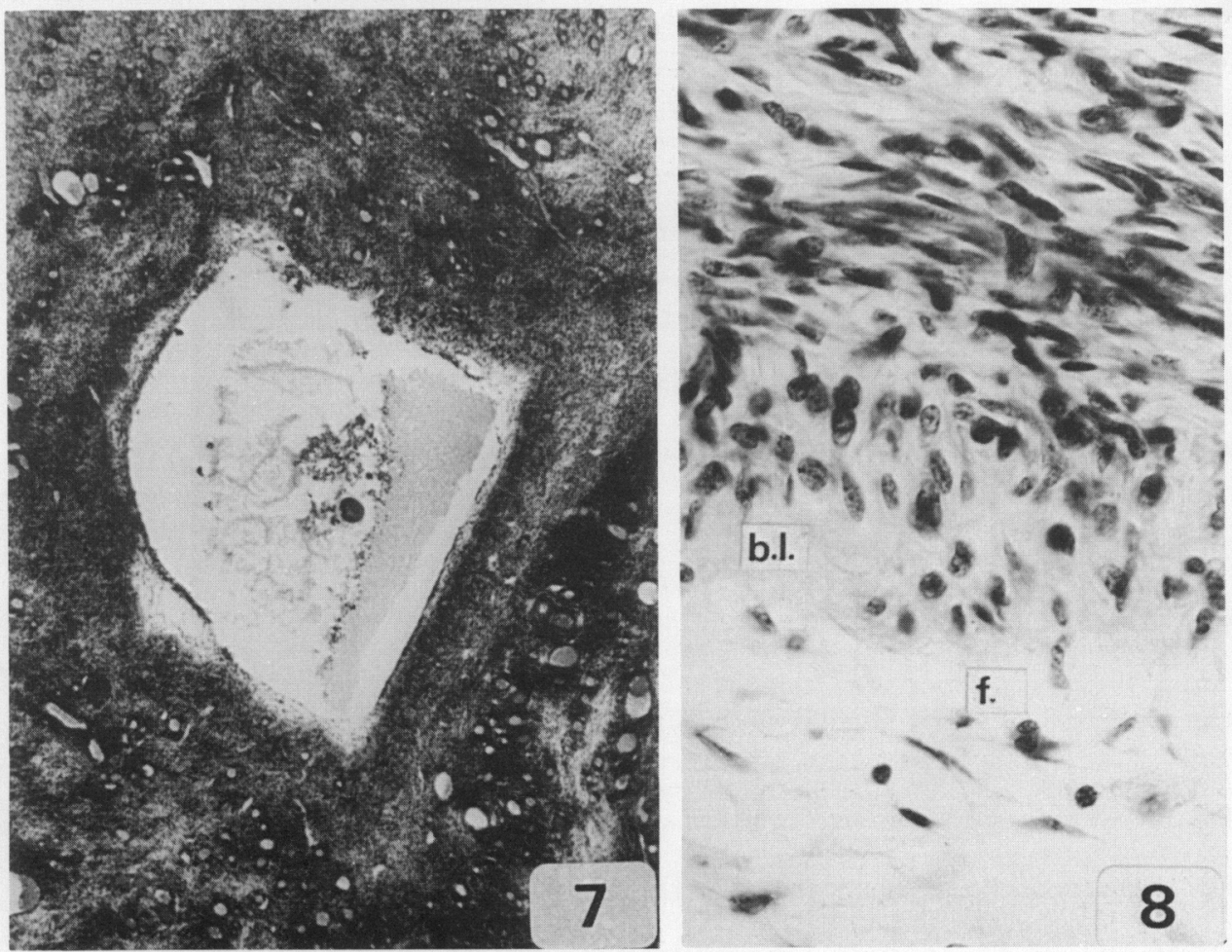
$>1 \mathrm{~mm}$ in diameter, $56 \%(434 / 777)$ were in the prometaphase stage. In atretic follicles only $10 \%$ $(69 / 690)$ presented a GVBD and 20\% (135-690) a necrotic oocyte.

The percentage of oocytes showing a GV decreased with the progression of follicular atresia (Table 2). The percentages of oocytes with GVBD were significantly $(P<0.01)$ lower in follicles in very late atresia compared with follicles in late atresia (Table 2). The percentages of necrotic oocytes significantly $(P<0.01)$ increased from marked atresia to very late atresia (Table 2$)$.

Table 2. Oocyte status in relation to follicle quality

\begin{tabular}{|c|c|c|c|c|c|c|}
\hline \multirow[b]{2}{*}{$\begin{array}{l}\text { Oocyte } \\
\text { status }\end{array}$} & \multicolumn{6}{|c|}{ Quality of follicles } \\
\hline & Healthy & $\begin{array}{c}\text { Early } \\
\text { atresia }\end{array}$ & $\begin{array}{c}\text { Marked } \\
\text { atresia }\end{array}$ & $\begin{array}{c}\text { Late } \\
\text { atresia }\end{array}$ & $\begin{array}{l}\text { Very late } \\
\text { atresia }\end{array}$ & Total \\
\hline GV & $291(100)$ & $149(99)$ & $158(92)^{\mathrm{b}}$ & $156(60)^{d}$ & $23(22)^{d}$ & 777 (79) \\
\hline GVBD & 0 & $2(1)$ & $12(7)^{\mathrm{a}}$ & $48(18)^{d}$ & $7(7)^{\mathfrak{c}}$ & $69(7)$ \\
\hline Necrotic & $\begin{array}{r}0 \\
291\end{array}$ & $\begin{array}{r}0 \\
151\end{array}$ & $\underset{172}{2(1)}$ & $\begin{array}{r}58(22)^{d} \\
262\end{array}$ & $\begin{array}{r}75(71)^{d} \\
105\end{array}$ & $\begin{array}{l}135(14) \\
981\end{array}$ \\
\hline
\end{tabular}

Percentages in parentheses.

Significantly different from the observed value in the earlier stage of atresia; $\mathrm{a}, P<0.05 ; \mathrm{b}, P<0.02 ; \mathrm{c}, P<0.01$; , $P<0.001$.

Table 3. Oocyte status in relation to the presence of a cumulus mass around the oocyte in atretic follicles

\begin{tabular}{lcc}
\hline & Cumulus-enclosed & Denuded \\
\hline GV & $473(94)^{*}$ & $13(7)$ \\
GVBD & $23(5)^{*}$ & $46(25)$ \\
Necrotic & $8(1)^{*}$ & $127(68)$ \\
\hline
\end{tabular}

Percentages in parentheses.

* Values significantly different from those for denuded oocytes $(P<0.001)$.

Fig. 9. Dictyate oocyte, healthy follicle, $\times 480$.

Fig. 10. Peripheral germinal vesicle in the prometaphase stage, follicle in marked atresia, $\times 480$.

Fig. 11. Germinal vesicle breakdown, chromatin mass, follicle in marked atresia, $\times 480$.

Fig. 12. Germinal vesicle breakdown, metaphase I, follicle in marked atresia. The apparent small size of this oocyte is due to polar section, $\times 480$.

Fig. 13. Germinal vesicle breakdown, metaphase II and polar body, follicle in early atresia, $\times 480$.

Fig. 14. Necrotic oocyte, occurrence of several pseudo-nuclei, follicle in late atresia, $\times 480$.

Fig. 15. Necrotic oocyte, fragmentation and pseudo-nuclei, follicle in late atresia, $\times 480$.

Fig. 16. Necrotic oocyte, empty zona pellucida, follicle in very late atresia, $\times 480$. 

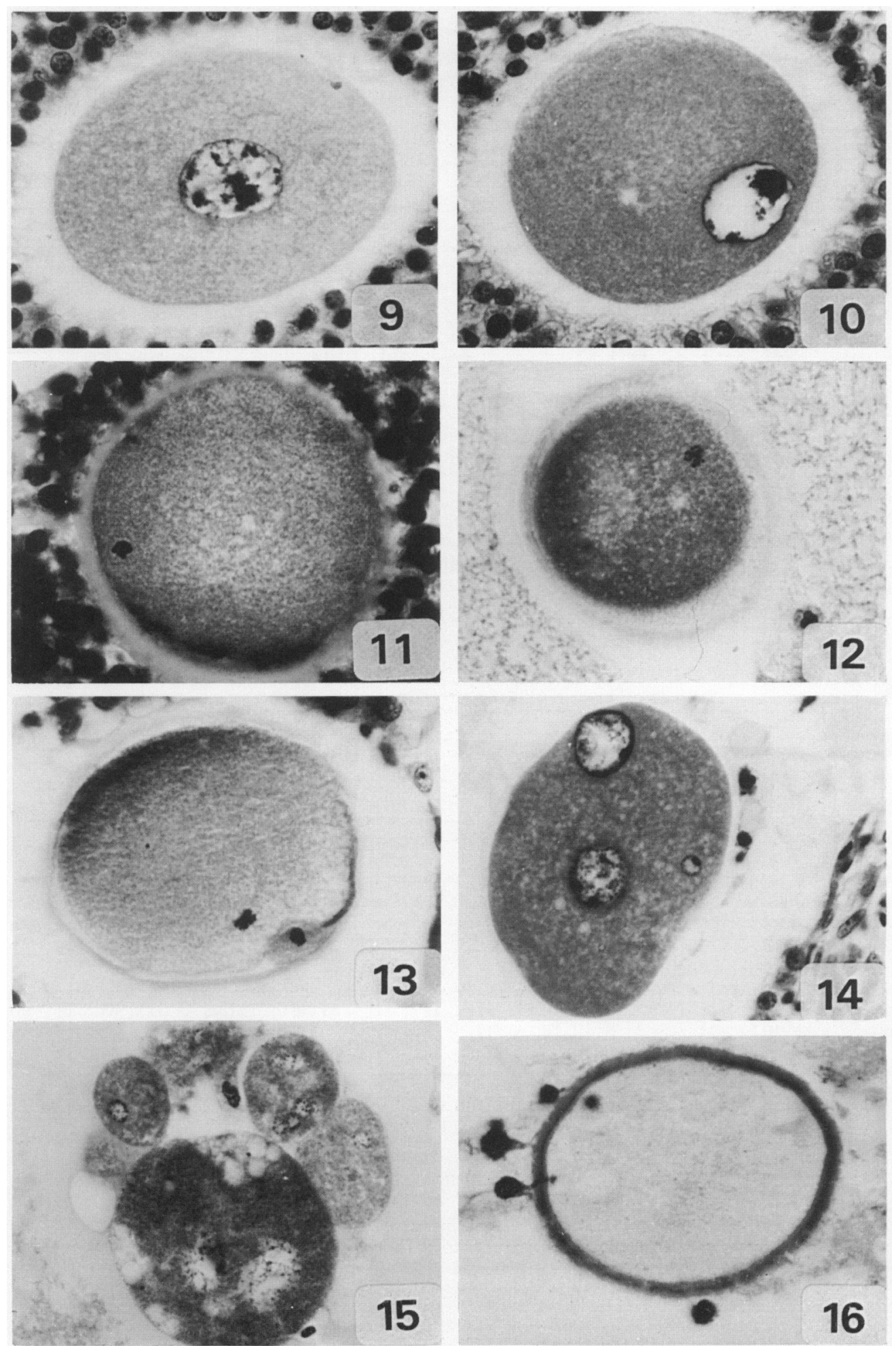


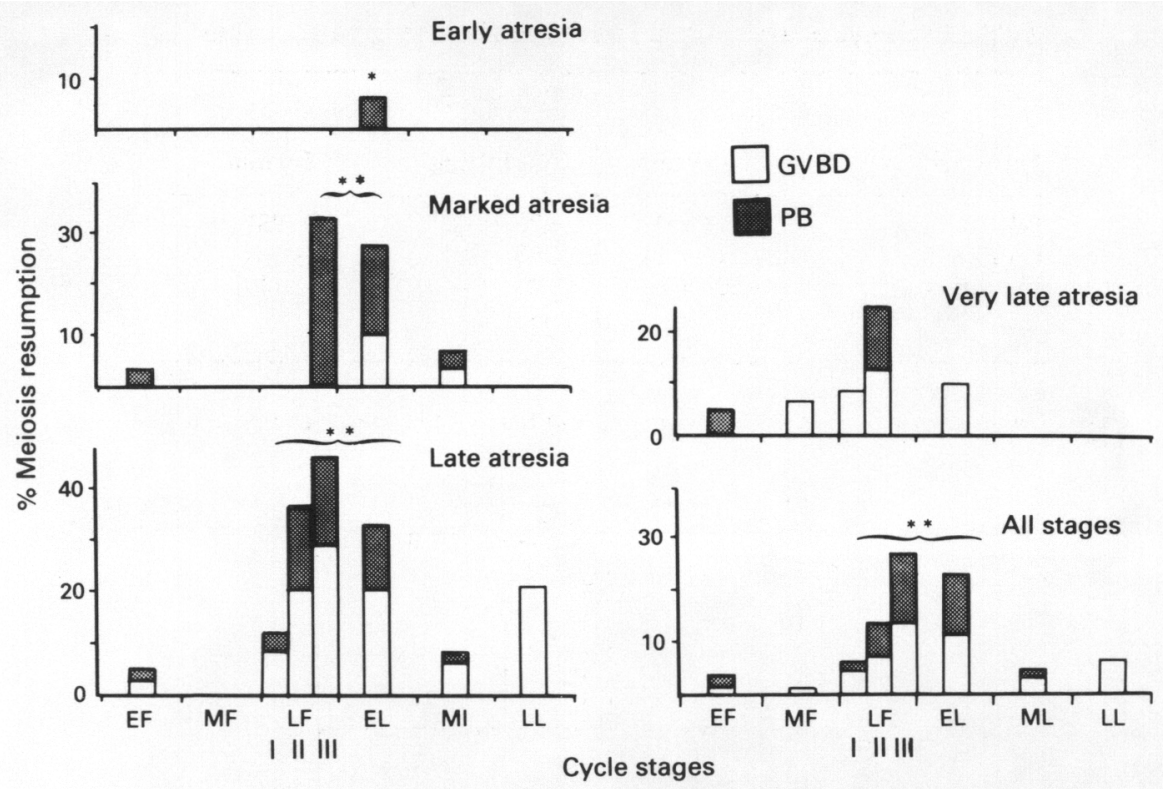

Fig. 17. The effect of atresia on occurrence of meiotic resumption in oocytes from atretic follicles during the menstrual cycle. Values significantly different from combined data of the other periods in the cycle; ${ }^{*} P<0.05,{ }^{* *} P<0.001$.

Table 4. Oocyte status in relation to follicle quality and stage of the menstrual cycle

\begin{tabular}{|c|c|c|c|c|c|c|c|c|c|}
\hline \multirow{3}{*}{$\begin{array}{l}\text { Quality } \\
\text { of } \\
\text { follicles }\end{array}$} & \multirow{3}{*}{$\begin{array}{l}\text { Oocyte } \\
\text { status }\end{array}$} & \multicolumn{8}{|c|}{ Phases of the menstrual cycle } \\
\hline & & \multirow[t]{2}{*}{ EF } & \multirow[t]{2}{*}{ MF } & \multicolumn{3}{|c|}{ LF } & \multirow[t]{2}{*}{ EL } & \multirow[t]{2}{*}{ ML } & \multirow[t]{2}{*}{ LL } \\
\hline & & & & $\mathbf{I}$ & II & III & & & \\
\hline $\begin{array}{l}\text { Early } \\
\text { atresia }\end{array}$ & $\begin{array}{l}\text { GV } \\
\text { GVBD } \\
\text { Necrotic }\end{array}$ & $\begin{array}{l}19(100) \\
0 \\
0\end{array}$ & $\begin{array}{l}19(100) \\
0 \\
0\end{array}$ & $\begin{array}{l}12(100) \\
0 \\
0\end{array}$ & $\begin{array}{l}17(100) \\
0 \\
0\end{array}$ & $\begin{array}{l}12(100) \\
0 \\
0\end{array}$ & $\begin{array}{l}25(93) \\
\frac{2(7)^{\mathrm{a}}}{0}\end{array}$ & $\begin{array}{l}34(100) \\
0 \\
0\end{array}$ & $\begin{array}{l}11(100) \\
0 \\
0\end{array}$ \\
\hline $\begin{array}{l}\text { Marked } \\
\text { atresia }\end{array}$ & $\begin{array}{l}\text { GV } \\
\text { GVBD } \\
\text { Necrotic }\end{array}$ & $\begin{array}{rr}30 & (97) \\
1 & (3) \\
0 & \end{array}$ & $\begin{array}{l}23(100) \\
0 \\
0\end{array}$ & $\begin{array}{l}21(100) \\
0 \\
0\end{array}$ & $\begin{aligned} 21 & (95) \\
0 & \\
1 & (5)\end{aligned}$ & $\begin{array}{ll}4 & (67) \\
2 & (33) \\
0 & \end{array}$ & $\begin{array}{c}17(68) \\
7(28)^{\mathrm{b}} \\
1(14)\end{array}$ & $\begin{array}{rr}26 & (93) \\
2 & (7) \\
0 & \end{array}$ & $\begin{array}{l}16(100) \\
0 \\
0\end{array}$ \\
\hline $\begin{array}{l}\text { Late } \\
\text { atresia }\end{array}$ & $\begin{array}{l}\text { GV } \\
\text { GVBD } \\
\text { Necrotic }\end{array}$ & $\begin{array}{rr}28 & (78) \\
2 & (5) \\
6 & (17)\end{array}$ & $\begin{array}{rr}30 & (91) \\
0 & \\
3 & (9)\end{array}$ & $\begin{array}{rr}17 & (65) \\
3 & (12) \\
6 & (23)\end{array}$ & $\begin{array}{rr}12 & (55) \\
8 & (36) \\
2 & (9)\end{array}$ & $\begin{aligned} 8 & (36) \\
10 & (46) \\
4 & (18)\end{aligned}$ & $\begin{array}{l}19(38) \\
17(33)^{\mathrm{b}} \\
15(29)\end{array}$ & $\begin{array}{rr}31 & (58) \\
4 & (8) \\
18 & (34)\end{array}$ & $\begin{aligned} 11 & (58) \\
4 & (21) \\
4 & (21)\end{aligned}$ \\
\hline $\begin{array}{l}\text { Very late } \\
\text { atresia }\end{array}$ & $\begin{array}{l}\text { GV } \\
\text { GVBD } \\
\text { Necrotic }\end{array}$ & $\begin{array}{rr}6 & (21) \\
1 & (4) \\
21 & (75)\end{array}$ & $\begin{array}{lr}4 & (31) \\
1 & (7) \\
8 & (62)\end{array}$ & $\begin{array}{rr}3 & (25) \\
1 & (8) \\
8 & (67)\end{array}$ & $\begin{array}{ll}0 & \\
2 & (25) \\
6 & (75)\end{array}$ & $\begin{array}{ll}2 & (50) \\
0 & \\
2 & (50)\end{array}$ & $\begin{array}{r}3(15) \\
2(10) \\
15(75)\end{array}$ & $\begin{array}{ll}3 & (27) \\
0 & \\
8 & (73)\end{array}$ & $\begin{array}{ll}2 & (22) \\
0 & \\
7 & (78)\end{array}$ \\
\hline $\begin{array}{l}\text { All } \\
\text { stages }\end{array}$ & $\begin{array}{l}\text { GV } \\
\text { GVBD } \\
\text { Necrotic }\end{array}$ & $\begin{array}{rr}83 & (73) \\
4 & (3) \\
27 & (24)\end{array}$ & $\begin{array}{rr}76 & (86) \\
1 & (1) \\
11 & (13)\end{array}$ & $\begin{array}{rr}53 & (75) \\
4 & (6) \\
14 & (19)\end{array}$ & $\begin{array}{rr}50 & (72) \\
10 & (15) \\
9 & (13)\end{array}$ & $\begin{aligned} 26 & (59) \\
12 & (27) \\
6 & (14)\end{aligned}$ & $\begin{array}{l}64(52) \\
28(23)^{\mathrm{b}} \\
31(25)\end{array}$ & $\begin{array}{rr}94 & (75) \\
6 & (5) \\
26 & (20)\end{array}$ & $\begin{array}{rr}40 & (73) \\
4 & (7) \\
11 & (20)\end{array}$ \\
\hline
\end{tabular}

Phases of the menstrual cycle: $\mathrm{EF}=$ early follicular; $\mathrm{MF}=$ mid-follicular; $\mathrm{LF}=$ late follicular; $\mathrm{EL}=$ early luteal; $M L=$ mid-luteal; $L L=$ late luteal.

Percentages in parentheses.

Groups of underlined values significantly different from the combined values from the other parts of the cycle; a, $P<0.05 ; \mathrm{b}, P<0.001$. 
Table 5. Oocyte status in relation to the diameter of atretic follicles

\begin{tabular}{lccc}
\hline & \multicolumn{3}{c}{ Follicle size } \\
\cline { 2 - 4 } Oocyte status & $1.0-1.9 \mathrm{~mm}$ & $2 \cdot 0-4.9 \mathrm{~mm}$ & $\geq 5.0 \mathrm{~mm}$ \\
\hline GV & $149(51)^{\mathrm{b}}$ & $270(82)^{\mathrm{a} . b}$ & $67(93)^{\mathrm{a}}$ \\
GVBD & $32(11)$ & $33(10)$ & 4 \\
Necrotic & $109(38)^{\mathrm{c}}$ & $25(8)^{\mathrm{c}}$ & 1 \\
& & 328 & 72 \\
\hline
\end{tabular}

Percentages in parentheses.

Values significantly different from one another; a, $P<0.02 ; \mathrm{b} \& \mathrm{c}, P<0.001$.

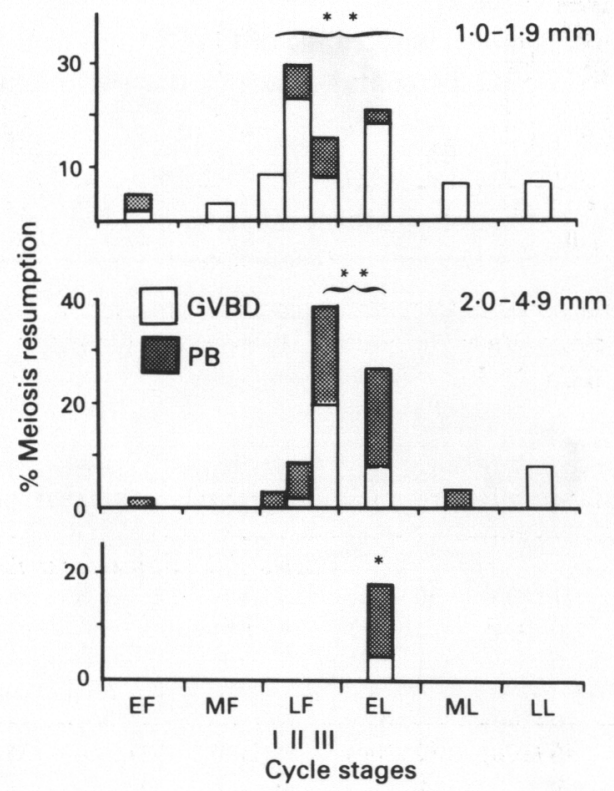

Fig. 18. The effect of follicle size on occurrence of meiotic resumption in oocytes from atretic follicles during the menstrual cycle. Values significantly different from the combined data of the other periods of the cycle; ${ }^{*} P<0 \cdot 01,{ }^{* *} P<0.001$.

There was a relation between the oocyte status and whether it was enclosed by cumulus cells: $94 \%$ of cumulus-enclosed oocytes exhibited a GV; 25 and $68 \%$ of denuded oocytes underwent GVBD and were necrotic respectively (Table 3).

During the menstrual cycle the percentages of oocytes with GVBD increased during the periovulatory period. Amongst oocytes + GVBD, 73\% (50/69) were observed from phase II in the late follicular phase to the early luteal phase and $23 \%$ (19/69) during the other periods of the cycle (Fig. 17; Table 4). The oocytes + GVBD observed in early atretic follicles were only seen during the early luteal phase. Follicles in marked atresia mainly showed oocytes with GVBD during the preovulatory phase III (after the gonadotrophin surge) and the early luteal phase. Follicles in late atresia showed high percentages of oocytes + GVBD during the preovulatory phases II and III (during and after the gonadotrophin surge), the early luteal phase and also, but to a lesser degree, during the late luteal phase. For follicles in very late atresia, there was no significant change in the percentages of oocytes + GVBD during the menstrual cycle. In addition the earlier that atresia 
occurred the higher the capacity of the oocytes to extrude a polar body: for follicles in early and marked atresia, respectively, 100 and $75 \%$ of oocytes showed polar bodies, and for follicles in late and very late atresia only 36 and $29 \%$, respectively, had polar bodies $(P<0.001)$ (Fig. 17).

\section{Oocyte status and size of the follicle}

A close relationship was found between oocyte status and follicle size (Table 5). Although the mean percentage of oocytes + GVBD was not related to the follicle size the percentages of oocytes with GV or necrotic were closely related to follicle size. The smaller the follicles were, the higher the percentage of necrotic oocytes. This phenomenon was related to (i) high percentages of very late atresia in smaller follicles ( $91 \%$ of very late atresia in $1.0-1.9 \mathrm{~mm}$ follicles) due to shrinkage occurring as the follicular atresia progresses and (ii) high percentage of necrotic oocytes $(71 \%)$ in the later stage of follicle atresia (Table 2).

As observed for the relation between percentage of GVBD and degree of follicular atresia, there was a significant increase of GVBD percentage during the periovulatory period in relation to

Table 6. Oocyte status in relation to follicle diameter and stage of the menstrual cycle

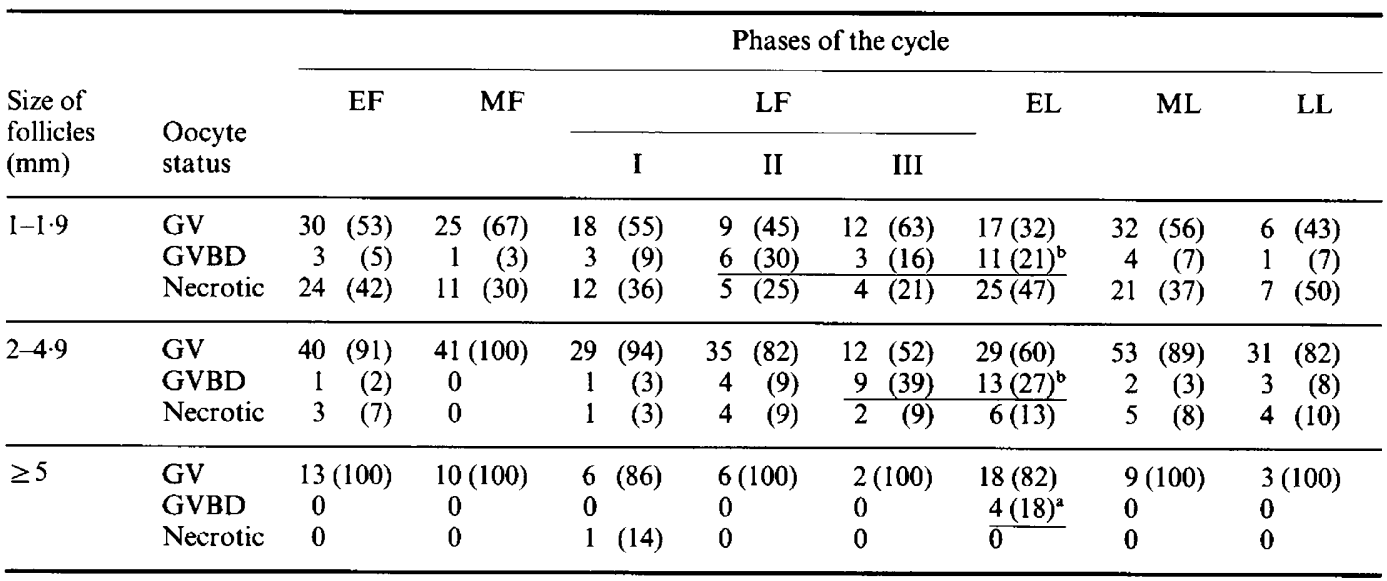

Phases of the menstrual cycle: $\mathrm{EF}=$ early follicular; $\mathrm{MF}$ = mid-follicular; $\mathrm{LF}=$ late follicular; $\mathrm{EL}=$ early luteal; $\mathrm{ML}=$ mid-luteal; $\mathrm{LL}=$ late luteal.

Percentages in parentheses.

Groups of underlined values significantly different from the combined data of the other parts of the cycle; a, $P<0.02 ;$ b,$P<0.001$.

Table 7. Influence of the cycle periods on follicle size, stages of atresia and oocyte status

\begin{tabular}{|c|c|c|c|c|c|c|c|c|c|c|}
\hline & \multicolumn{4}{|c|}{ Stages of atresia } & \multicolumn{3}{|c|}{ Follicle size $(\mathrm{mm})$} & \multicolumn{3}{|c|}{ Oocyte status } \\
\hline & Early & Marked & Late & $\begin{array}{l}\text { Very } \\
\text { late }\end{array}$ & $\begin{array}{l}1.0 \\
1.9\end{array}$ & $\begin{array}{l}2 \cdot 0- \\
4.9\end{array}$ & $\geq 5 \cdot 0$ & GV & GVBD & Necrotic \\
\hline $\begin{array}{l}\text { Periovulatory } \\
\text { period }\end{array}$ & $\begin{array}{c}56 \\
(24)\end{array}$ & $\begin{array}{r}53 \\
(22)\end{array}$ & $\begin{array}{r}95 \\
(40)\end{array}$ & $\begin{array}{c}32 \\
\text { (14) }\end{array}$ & $\begin{array}{r}92 \\
(39)\end{array}$ & $\begin{array}{l}114 \\
(48)\end{array}$ & $\begin{array}{c}30 \\
(13)\end{array}$ & $\begin{array}{c}140 \\
(59)^{2}\end{array}$ & $\begin{array}{c}50 \\
(21)^{\mathrm{b}}\end{array}$ & $\begin{array}{c}46 \\
(20)\end{array}$ \\
\hline $\begin{array}{l}\text { Other periods } \\
\text { in cycle }\end{array}$ & $\begin{array}{c}95 \\
(21)\end{array}$ & $\begin{array}{l}119 \\
(26)\end{array}$ & $\begin{array}{l}167 \\
(37)\end{array}$ & $\begin{array}{c}73 \\
\text { (16) }\end{array}$ & $\begin{array}{l}198 \\
(44)\end{array}$ & $\begin{array}{l}214 \\
(47)\end{array}$ & $\begin{array}{l}42 \\
(9)\end{array}$ & $\begin{array}{c}346 \\
(76)^{2}\end{array}$ & $\begin{array}{l}19 \\
(4)^{b}\end{array}$ & $\begin{array}{c}89 \\
(20)\end{array}$ \\
\hline
\end{tabular}

Percentages in parentheses.

Values significantly different from one another; $\mathrm{a} \& \mathrm{~b}, P<0.001$. 
follicle size (Fig. 18; Table 6). The largest follicles $(5-12 \mathrm{~mm})$ showed oocytes + GVBD only during the early luteal phase. The middle-sized follicles $(2 \cdot 0-4.9 \mathrm{~mm})$ showed oocytes + GVBD during the phase III of the late follicular phase and during the early luteal phase. The smallest follicles $(1.0-1.9 \mathrm{~mm})$ showed oocytes + GVBD during the preovulatory phases II and III and the early luteal phase.

There was a close relationship between follicle size and the capacity of the oocyte to extrude a polar body. Among the 1.0-1.9, 2.0-4.9 and $\geqslant 5.0 \mathrm{~mm}$ follicles, 22,62 and $75 \%$ oocytes showing a polar body were observed in follicles (mean diameter \pm s.e.m. $=3.48 \pm 0.4 \mathrm{~mm}$ ), significantly larger $(P<0.001)$ than those (mean diameter \pm s.e.m. $=1.86 \pm 0.16 \mathrm{~mm})$ with a GVBD only.

The percentage of GVBD was clearly related to both the follicle size and the stage of atresia. We examined whether the significant increase of GVBD percentage during the periovulatory period was related to a change in follicle size or degree of atresia compared to the rest of the menstrual cycle (Table 7). No difference was seen in the distribution of follicle sizes and stages of atresia between these two periods of the menstrual cycle.

\section{Discussion}

Shea, Baker \& Latour (1975) and McNatty et al. (1979) observed 2.0 and 3.6\% of collected human oocytes with GVBD respectively. Our results show that $7 \%(69 / 981)$ of oocytes + GVBD are present inside the ovaries. We never observed GVBD in oocytes from healthy follicles before the preovulatory stage. The percentage of GVBD increased with the degree of follicular atresia, but atresia of the human follicle is not necessarily associated with the rupture of the germinal vesicle in the oocyte. The most interesting phenomenon which we have observed was the time in the menstrual cycle when the oocyte preferentially exhibits GVBD.

In atretic follicles the percentage of oocytes with GVBD increases during the period of ovulation, i.e. the time when oocyte maturation occurs in the preovulatory follicle. This periovulatory rise is not related to an alteration in the percentages of follicle sizes and stages of atresia. Such a cyclic resumption of meiosis is clearly shown for oocytes of the largest follicles which are also the most recently atretic (early and marked atresia). In follicles $>5 \mathrm{~mm}$ in diameter, GVBD occurs only after ovulation and $75 \%(3 / 4)$ of the oocytes reached maturity and extruded a polar body. The oocytes inside smaller follicles or in follicles at a more advanced stage of atresia (late and very late) ruptured their nucleus much earlier, because of modified intrafollicular steroid levels (McNatty et al., 1979) or a particular sensitivity to tonic levels of gonadotrophins, and only 35\% $(19 / 55)$ extruded a polar body. The ability of oocytes from atretic follicles to achieve complete nuclear maturation is related both to their size and to the earlier stages of atresia.

Amongst the oocytes retaining their germinal vesicle in follicles of $>1 \mathrm{~mm}$ diameter, $56 \%$ no longer had the typical appearance of the dictyate nucleus and were in the prometaphase stage (Thibault, 1972). That particular stage was also called "clumped chromatin" by Sanyal et al. (1976) who observed 66 such oocytes among $152(43 \%)$ coming from normal cyclic ovaries. These oocytes might resume meiosis in vitro more readily than do dictyate oocytes, as mentioned by McNatty $e t$ al. (1979) who observed that oocytes from atretic follicles were more able to complete the first meiotic division in vitro than were oocytes from healthy follicles. The results obtained by others show the percentages of GVBD in primate oocytes in vitro as between 30 and $60 \%$ (rhesus monkey: Edwards, 1965; Gould \& Graham, 1976; cynomolgus monkey: Thibault, Gerard \& Menezo, 1975; man: Pincus \& Saunders, 1939; Kennedy \& Donahue, 1969; Shea et al., 1975; McNatty et al., 1979; Tsuji, Sowa \& Nakano, 1985). The positive results obtained concerning in-vitro maturation of the isolated human oocyte (i.e. complete resumption of meiosis from dictyate oocytes) therefore seem to be overestimated since fewer than half of the cultured oocytes may be at the dictyate stage at the time of recovery. These results must lead to re-examination of the process of spontaneous resumption of meiosis in vitro. There may be a complete removal of inhibition, allowing a dictyate 
oocyte to resume its meiosis, or completion of an in-vivo process that starts in association with the early atresia.

Most of the oocytes we observed were in atretic follicles and it was impossible to know whether they were able to be fertilized and to produce embryos. However, in the ewe Moor \& Trounson (1977) have obtained embryos after in-vitro fertilization of oocytes coming from atretic follicles. Since early GVBD in oocytes from atretic follicles appears in vivo specifically at the time of ovulation, it can be postulated that nuclear maturation in healthy full-sized human oocytes could be controlled by a dual mechanism: (i) a removal of the inhibition exerted on the nucleus by the follicle and (ii) a stimulation (by pituitary or intraovarian factor) which leads to the rupture of the germinal vesicle. This hypothesis is supported by the low success rate in attempts to produce invitro maturation of isolated dictyate primate oocytes collected from healthy follicles (B. Lefèvre, A. Gougeon \& J. Testart, unpublished data). Further investigations are needed to clarify the exact causes of meiotic resumption in the human oocyte.

We thank Pr E. Martin, Dr H. Mazabraud, Pr E. Papiernik and Dr M. Prade for providing clinical material; Françoise Nomé for technical assistance; and Dr R. Forman and Dr D. Mortimer for the English translation.

\section{References}

Allen, E., Pratt, J.P., Newell, Q.U. \& Bland, L.J. (1930) Human ova from large follicles; including a search for maturation divisions and observations on atresia. Am. J. Anat. 46, 1-53.

Bomsel-Helmreich, O., Gougeon, A., Thébault, A., Saltarelli, D., Milgrom, E., Frydman, R. \& Papiernik, E. (1979) Healthy and atretic human follicles in the preovulatory phase: differences in evolution of follicular morphology and steroid content of follicular fluid. J. clin. Endocr. Metab. 48, 686-694.

Channing, C.P. \& Pomerantz, S.H. (1981) Studies on an oocyte maturation inhibitor partially purified from porcine and human follicular fluids. In Intragonadal Regulation of Reproduction, pp. 81-96. Eds P. Franchimont \& C. P. Channing. Academic Press, London.

Corner, G.W., Jr (1956) The histological dating of the human corpus luteum of menstruation. Am. J. Anat. 98, 377-401.

Cran, D.G., Osborn, J.C. \& Rushton, D. (1983) Thecal vasculature and oocyte maturation during follicular atresia in the sheep and pig. Reprod. Nutr. Dévelop. 23, 285-292.

Downs, S.M., Coleman, D.L., Ward-Bailey, P.F. \& Eppig, J.J. (1985) Hypoxanthine is the principal inhibitor of murine oocyte maturation in a low molecular weight fraction of porcine follicular fluid. Proc. natn. Acad. Sci. U.S.A. 82, 454-458.

Edwards, R.G. (1965) Maturation in vitro of mouse, sheep, cow, pig, rhesus monkey and human ovarian oocytes. Nature, Lond. 208, 349-351.

Foote, W.D. \& Thibault, C. (1969) Recherches expérimentales sur la maturation in vitro des ovocytes de truie et de veau. Annls Biol. anim. Biochim. Biophys. 9, 329-349.

Friedrich, F., Breitenecker, G., Pavelka, R. \& Golob, E. (1975) Die Morphologie der Eizellen von Bläschenfollikeln bei normaler und gestörter Eierstockfunktion der Frau. Arch. Gynäk. 218, 269-280.
Gougeon, A. \& Lefèvre, B. (1983) Evolution of the diameters of the largest healthy and atretic follicles during the human menstrual cycle. J. Reprod. Fert. 69, 497-502.

Gould, K.G. \& Graham, C.E. (1976) Maturation in vitro of oocytes recovered from prepubertal rhesus monkeys. J. Reprod. Fert. 46, 269-270.

Ingram, D.L. (1962) Atresia. In The Ovary, 1st edn, vol. 1, pp. 247-273. Ed. S. Zuckerman. Academic Press, New York.

Kennedy, J.F. Donahue, R.P. (1969) Human oocytes: maturation in chemically defined media. Science, N.Y. 164, 1292-1293.

McNatty, K.P., Moore Smith, D., Makris, A., Osathanondh, R. \& Ryan, K.J. (1979) The microenvironment of the human antral follicle: interrelationships among the steroid levels in antral fluid, the population of granulosa cells, and the status of the oocyte in vivo and in vitro. J. clin. Endocr. Metab. 49, 851-860.

Meyer, N.L. \& Longo, F.J. (1979) Cytological events associated with in vitro aged and fertilized rabbit eggs. Anat. Rec. 195, 357-374.

Moor, R.M. \& Trounson, A.O. (1977) Hormonal and follicular factors affecting maturation of sheep oocytes in vitro and their subsequent developmental capacity. J. Reprod. Fert., 49, 101-109.

Pincus, G. \& Saunders, B. (1939) The comparative behavior of mammalian eggs in vivo and in vitro. VI The maturation of human ovarian ova. Anat. Rec. 75, 537-544.

Sanyal, M.K., Taymor, M.L. \& Berger, M.J. (1976) Cytologic features of oocytes in the adult human ovary. Fert. Steril. 27, 501-510.

Seibel, M.M., Smith, D.M., Levesque, L., Borten, M. \& Taymor, M.L. (1982) The temporal relationship between the Luteinizing Hormone surge and human oocyte maturation. Am. J. Obstet. Gynec. 142, $568-572$. 
Shea, B.F., Baker, R.D. \& Latour, J.P.A. (1975) Human follicular oocytes and their maturation in vitro. Fert. Steril. 26, 1075-1082.

Thibault, C. (1972) Final stages of mammalian oocyte maturation. In Oogenesis, pp. 397-411. Eds J. D. Biggers \& A. W. Schuetz. University Park Press, Baltimore.

Thibault, C. (1977) Are follicular maturation and oocyte maturation independent processes? J. Reprod. Fert. 51, 1-15.

Thibault, C., Gerard, M. \& Menezo, Y. (1975) Preovulatory and ovulatory mechanisms in oocyte maturation. J. Reprod. Fert. 45, 605-610.
Tsafriri, A., Pomerantz, S.H. \& Channing, C.P. (1976) Inhibition of oocyte maturation by porcine follicular fluid: partial characterization of the inhibitor. Biol. Reprod. 14, 511-516.

Tsuji, K., Sowa, M. \& Nakano, R. (1985) Relationship between human oocyte maturation and different follicular sizes. Biol. Reprod. 32, 413-417.

Westergaard, L., Byskov, A.G., Andersen, C.Y., Grinsted, J. \& McNatty, K.P. (1984) Is resumption of meiosis in the human preovulatory oocyte triggered by a meiosis-inducing substance (MIS) in the follicular fluid? Fert. Steril. 41, 377-384.

Received 27 January 1986 